\title{
Oil Revenue Shocks and the Growth of the Non-Oil Sector in an Oil-Dependent Economy: The Case of Oman
}

\author{
Ibtisam Al-Abri*, Gülcan Önel, Kelly A. Grogan \\ Food and Resource Economics Department, University of Florida, Gainesville, USA \\ Email: ‘ialabri@squ.edu.om, gulcan.onel@ufl.edu, kellyagrogan@ufl.edu
}

How to cite this paper: Al-Abri, I., Önel, G. and Grogan, K.A. (2019) Oil Revenue Shocks and the Growth of the Non-Oil Sector in an Oil-Dependent Economy: The Case of Oman. Theoretical Economics Letters, 9, 785-800.

https://doi.org/10.4236/tel.2019.94052

Received: February 20, 2019

Accepted: April 9, 2019

Published: April 12, 2019

Copyright ( 2019 by author(s) and Scientific Research Publishing Inc. This work is licensed under the Creative Commons Attribution International License (CC BY 4.0).

http://creativecommons.org/licenses/by/4.0/

\begin{abstract}
There is no consensus among economists on whether natural resource abundance is a curse or a blessing for countries heavily endowed with such resources. Oman is a small oil-exporting country that heavily relies on oil revenues. Recent adverse shocks to oil prices have left Oman's economy more vulnerable relative to other countries relying on oil for their main source of income. One reason for this outcome may be that Oman's private non-oil sector heavily depends on government spending and projects, which typically decelerate after negative oil shocks. Using a cointegrating Vector Autoregressive Regression (VAR) model and quarterly data covering the period 2000 to 2015, we evaluate the "oil-curse" phenomenon for Oman by exploring long-run and short-run relationships among economic growth sourced from non-oil producing sectors, oil revenues, and government expenditures. We also use causality tests and impulse responses to measure the extent of short-run and long-run macroeconomic implications of negative oil shocks for Oman. Results suggest that a sound fiscal policy that allows for true sectoral diversification of income is crucial to avoid an oil curse in Oman.
\end{abstract}

\section{Keywords}

Oil Curse, Economic Growth, Government Spending, Private Non-Oil Sector, Oman

\section{Introduction}

Recent adverse shocks to oils prices have left many oil-exporting economies that rely on oil as their main source of government revenue struggling [1]. The downfall of oil prices has renewed interest in an old question: Is the abundance 
of a natural resource, such as oil, a curse or a blessing for long-run economic growth? Standard theories of growth typically ignore possible effects of oil dependence on the economic growth process, and emphasize technological progress and capital accumulation as the main drivers of growth. Similarly, empirical studies of economic growth typically exclude oil-rich countries from their crosscountry comparisons, as these countries are not typically "poolable" with other countries in panel data used in such studies [2]. An oil-abundant, oil-exporting country-such as the Sultanate of Oman (Oman, hereafter)-has distinct features that require attention in empirical examinations of economic growth. First, most oil reserves are owned by the state, and oil earns most of the government revenues (i.e., fiscal implications). Second, oil revenues serve as the vehicle for public investment in the private, non-oil sector (i.e., real-sector implications). Third, there is little evidence to suggest that oil reserves in these countries will be diminishing any time soon; therefore, analyses of oil revenues and economic growth need to consider a long-term approach rather than a short-term perspective [2]. This study accounts for these unique characteristics in examining the dynamic relationships between oil revenues, government spending, and economic growth from the private non-oil sector in Oman.

Although Oman has been trying to diversify its revenue sources aside from oil and gas revenues, macroeconomic indicators suggest a continuing dependence on oil revenue in Oman. The share of oil revenue in total government revenues increased from $77 \%$ in 1995 to $81 \%$ in 2010 [3]. Because government revenue is tied strictly to oil revenue, negative oil price shocks adversely affect government spending, which reduces aggregate consumption and investment, leading to slower economic growth rates. The private non-oil sectors in Oman do not seem to be viable drivers of economic growth. Although the contribution of the services sector to overall GDP has been increasing over time, a closer look at the sources of this growth reveals that the services sector is directly or indirectly dependent on the oil sector. While $48 \%$ of total value added by the services sector in 2010 was sourced from the government service sector, which heavily relies on the government's oil revenues, the private services sector did not have a noticeable contribution to the GDP [3]. Consequently, $85 \%$ of Oman's total GDP is directly or indirectly linked to oil, with $48 \%$ of GDP made up of oil revenues and $37 \%$ of GDP from oil-dependent sectors [3].

In oil-exporting countries, the stream of government revenue is highly volatile, since a large portion of this revenue is derived from the oil sector through taxes and royalties. Therefore, fiscal policy in an oil-dependent country could be a primary determinant of the domestic absorption of an oil shock. In other words, fluctuations in oil revenues could be transmitted to the (non-oil) economy through large fluctuations in government revenues [4] [5].

Oil price shocks tend to follow a nonstationary process; therefore, they can be long lasting and large in magnitude. This characteristic has important implications for fiscal policy. If there were a "steady-state" level for oil prices, the optimal fiscal policy response during periods of rising prices would be to save the 
excess over "steady-state" earnings for later when oil prices move below their steady-state levels. However, when favorable oil price shocks are persistent and perceived to be permanent, government spending on nontradeables (e.g., wages and transfers) increases, prompting a resource re-allocation away from the tradeable sector to the non-tradeable sector [6] [7]. Even if the shock is perceived as temporary, accumulating budget surpluses in boom times at the expense of government spending is usually unpopular among the public in developing oil-exporting economies [8]. Conversely, a sudden fall in oil revenues may call for a downward adjustment in government expenditures, which may be costly [7] [9]. Investments may be disrupted when the government's oil revenues fall. Given the irreversible nature of public investments, the social costs of reducing capital expenditures could be high and unpopular [10].

One could argue that oil-exporting countries could utilize monetary policies to navigate through negative oil shocks. It is well-known in standard macroeconomic literature that a small open economy cannot simultaneously hold a fixed exchange rate system, full capital mobility or financially integrated markets, and monetary policy independence. One of the three elements needs to be suppressed in order to attain the remaining two [11]. Given that Oman is a small, open economy with minimal capital controls, the scope for monetary policy independence is limited. Therefore, attempts by the Central Bank of Oman (CBO) to stabilize the economy through a monetary policy will prove ineffective. CBO's fundamental commitment to preserve the fixed exchange rate essentially implies polices that are predominantly fiscal in nature for the case of Oman.

In short, the argument that oil-dependent countries, such as Oman, could use monetary policy tools or higher fiscal surpluses obtained in times of high oil revenues in order to mediate the negative consequences of oil dependency does not necessarily hold. The remainder of this paper explores the "oil-curse" phenomenon by quantifying long-run and short-run relationships between government expenditures, oil revenues, and non-oil sector GDP growth. Unlike previous studies that do not distinguish between the overall growth and that of the non-oil sector [1] [5], we isolate the impact of oil revenue shocks on the growth sourced from the private non-oil sector, for which government spending plays a significant role. We utilize causality tests and impulse responses to measure the extent of short-run and long-run macroeconomic implications of oil revenue shocks for Oman using unique quarterly time series data from 2000 to 2015. The results suggest that the dependence of the private sector on the public sector in an oil-dependent economy could amplify the macroeconomic impacts of an adverse oil shock. As such, the government of Oman could implement further economic and structural reforms that foster the development of non-oil sectors independently from government projects that typically slow down with negative oil-shocks.

The rest of the paper is structured as follows: Section 2 provides the data and methods used, Section 3 provides the findings, and Section 4 concludes with implications for policy. 


\section{Literature Review}

In the shortrun, a rise in oil prices and favorable terms of trade increase demand for output, leading to higher levels of income and growth [4] [12] [13]. In the longrun, however, the literature provides different predictions on the net impact of oil shocks on growth and other macroeconomic indicators. Earlier studies use the "Dutch disease" concept (a phenomenon first experienced in the Netherlands after the large, but short-lived, discovery of gas in the 1960s) to explain the indirect adverse effects of natural resource abundance. This literature tends to treat natural resource revenues as temporary, and predicts that an exogenous unexpected increase in revenues from the resource will result in real exchange rate appreciation and a fall in output and employment of the non-resource traded goods sector, such as the manufacturing sector [14] [15]. However, since natural resource abundance in cases of 'Dutch disease' is fairly short-lived, the economy as a whole does not need to incur long-run adverse implications, unless there are important frictions in preventing re-adjustment [16].

More recent studies have tried to explain the disappointing growth performance observed in resource-abundant economies compared to non-resource-based economies of similar levels of development. Oil-exporting economies are a striking example of such a "natural resource curse" [17] [18]. Empirical support for the so-called "natural resource curse" was first provided by Sachs and Warner [17], who showed the existence of a negative relationship between real GDP growth per capita and different measures of resource abundance. The concept of "resource-curse" (or, more specifically, "oil-curse") continues to be the subject of debate in the literature [2] [19] [20] [21].

Eltony and Al-Awadi [22] examine the effect of oil price fluctuations on macroeconomic growth indicators for Kuwait. They find that macroeconomic variables respond to oil price shocks and that government fiscal policy is sensitive to oil prices volatility. Ayadi [23] and Iwayemi and Fowowe [24] study the impact of oil price changes on macroeconomic variables of Nigeria and find that a positive oil price shock does not necessarily improve economic growth or industrial production. Mehrara [25] explores whether oil revenues explain changes in industrial production for 13 oil-exporting countries in the Middle East and North Africa and finds an asymmetric association between oil revenue fluctuations and GDP growth, where a negative shock in oil revenues reduces output growth, but positive shocks have a limited effect. Farzanegan and Markwardt [12] find that an increase in industrial output in Iran is associated with increasing oil prices, and that both increasing and decreasing oil prices will result in higher inflation rates.

A few studies specifically examine the role of government spending on how oil price (or, revenue) shocks are diffused into the domestic economy in oil-exporting countries. Akpan [26] argues that a positive oil price shock plays a role in determining Nigerian fiscal policy and affects industrial output significantly. Jbir and Zouari-Ghorbel [27] shed light on the importance of government subsidies in 
Tunisia. They indicate that disturbances in oil prices indirectly influence economic growth and that government spending is the major player of transmission. Cologni and Manera [28] find that oil shocks cause a reallocation of economic activity between the private and public sectors and that higher oil revenues cause negative effects on private investment and capital. Moshiri and Banijashem [29] use a VAR model with annual data over the period 1979-2009 for six OPEC countries. They find that while oil price decreases lead to significant reduction in government revenue and output in the economy, higher oil prices do not lead to sustained economic growth. Hamdi and Sbia [5] assess the dynamic relationships between oil revenue, government spending, and economic growth in Bahrain. Results show that oil revenues still represent the main source of economic growth and account for a large share of the government budget.

Studies including Oman are scarce. Berument and Ceylan [30] explore how an oil price crisis changes industrial output growth for selected MENA countries, including Oman. Findings reveal that GDP growth in Iraq, Algeria, Kuwait, Oman, Jordan, Syria, Qatar, UAE, and Tunisia is affected by oil revenues. Similar to Hamdi and Sbia [5], Ahmad and Masan [31] test the associations between GDP, government expenditures and oil revenues for the case of Oman. Their results imply that in the longrun both oil revenues and government expenditures have positive associations with GDP. They argue that Omani economic growth is mainly driven by government spending and that oil revenue shocks play a major role in government spending volatility.

The channels by which oil revenues may affect the economic performance of the non-oil sector have not been systematically documented. This study accounts for the possibility that oil revenue shocks could lead to additional economic instability through the dependence of non-oil sectors on government spending. The hypothesis is that fiscal policy plays an important role in transmitting oil revenue shocks to the non-oil sector of the Omani economy, determining the net impact of the shock on the long-run growth of the non-oil sectors and the economy as a whole.

\section{Data and Methods}

This study utilizes quarterly data for the period 2000 to 2015 . All variables used in the analyses are in real local currency and in logarithmic form. Prior to modeling, the data have been adjusted for seasonality using the U.S. Census $\mathrm{Bu}$ reau'sX-13 methodology based on ARIMA modeling. Data are provided by the National Center for Statistical and Information, Oman. Three macroeconomic variables of interest are denoted as: 1) LREVOIL, 2) LEXP, and 3) LGDPNON. The first variable, logarithmic real oil revenues, (LREVOIL), are defined as real rents from oil and gas exports. Similar to other oil-abundant countries, revenues from the oil sector constitute the largest share of the Omani government's budget. An increasing oil revenue stream is typically accompanied by government expansion, while falling oil prices lead to a budget deficit. The second variable, 
logarithmic total real government spending in Oman,(LEXP),closely follows oil prices when oil prices are rising. However, government spending remains relatively high even when oil prices fluctuate downward due to high social and political pressure not to cut wages, salaries, and social benefit payments [33]. The three variables appear to move together with government spending (LEXP)being slightly sticky.

Figure 1 shows the movement of the non-oil portion of GDP, total government expenditures, and oil revenues in Oman during the period 2000-2015. Both non-oil GDP and government spending appear to follow oil revenues. However, government spending (LEXP) is sticky during times of diminishing oil revenues. That is, government expenditures do not adjust downward with falling oil prices. Figure 1 intuitively shows how the behavior of the non-oil GDP is parallel to that of government spending, which relies mainly on oil revenues. Oil prices, which determine oil revenues, are considered exogenous for a small oil-exporting country like Oman. Hence, the Omani government is the major player in "greasing the wheels" of economic activities and growth of the economy.

The objective of this paper is to test the short-run and long-run dynamic relationships between growth in the non-oil sector, oil revenues, and government spending in Oman from 2000 to 2015. The investigation will shed light on risks associated with the dependence of private investment on public investment in Oman. The first step of the estimation requires unit root testing for the three variables of interest [32]. We use the Augmented Dickey-Fuller tests (ADF) [33]) and Philips-Perron (PP) tests [34] for this purpose. After the nonstationarity of all variables at levels (or, stationarity at first differences) is confirmed, we proceed with testing the number of long-run cointegrating relationships between the three variables using the Johansen [35] cointegration test. By construction, Johansen [35] cointegration tests allow for up to two cointegrating relationships

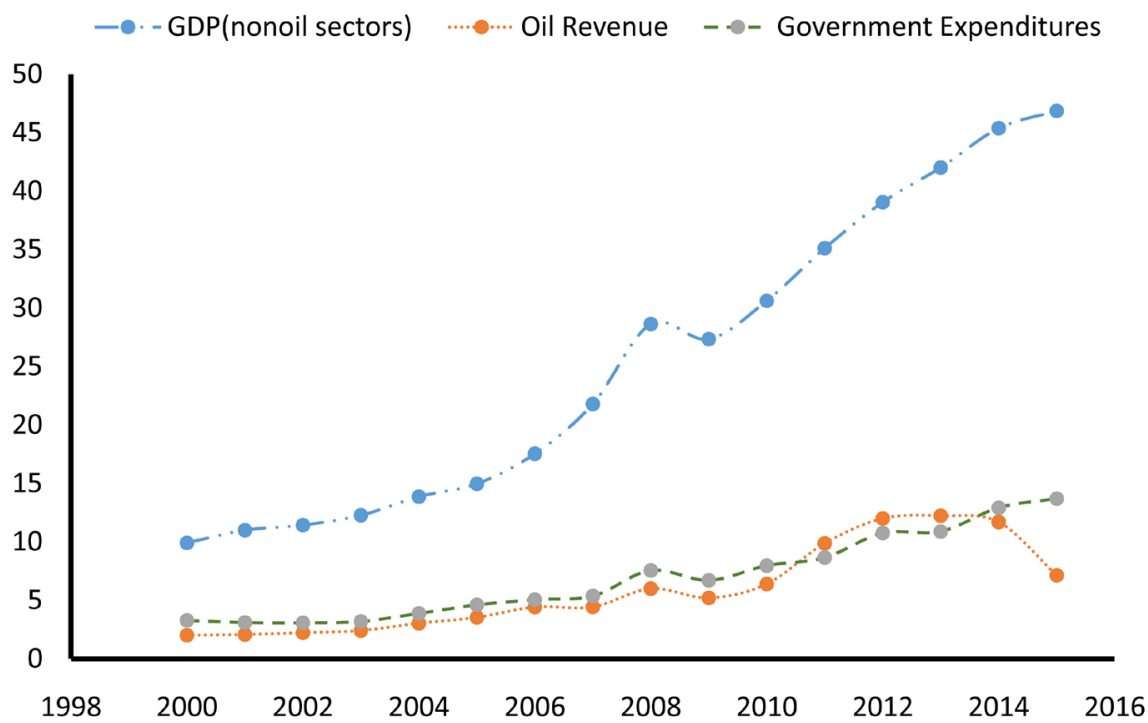

Figure 1. Logarithms of GDP from non-oil sector, oil revenues, and government expenditures in Oman, 2000-2015. 
in a Vector Auto Regressions (VAR) system made up of three variables. The final step of modeling is to estimate the short-run elasticities from the Vector Error Correction Model (VECM), which links the longrun to the short-run through what is called an Error Correction Term (ECT). For VECM to be valid, variables have to be integrated of order one, I(1), individually and cointegrated jointly at their levels. The error correction term (ECM) captures the disequilibrium in the long-run cointegrating relationship and provides a way to estimate the speed of adjustment at which the dependent variable returns to the long-run equilibrium level. Another advantage of VECM is that it also provides short-run causality among variables [36]. The VECM of the short-run relationships among growth of the non-oil sector's output, government spending, and oil revenues is as follows:

$$
\begin{aligned}
\triangle L \text { GDPNON }_{t}= & c_{1}+\sum_{i=1}^{p} \psi_{11}^{i} \Delta \operatorname{LGDPNON}_{t-i}+\sum_{i=1}^{p} \psi_{12}^{i} \Delta \text { LREVOIL }_{t-i} \\
& +\sum_{i=1}^{p} \psi_{13}^{i} \Delta L E X P_{t-i}+\lambda_{1} E C T_{t-1}+u_{1 t} \\
\Delta \text { LREVOIL }_{t}= & c_{2}+\sum_{i=1}^{p} \psi_{21}^{i} \Delta L G D P N O N_{t-i}+\sum_{i=1}^{p} \psi_{22}^{i} \Delta L R E V O I L_{t-i} \\
& +\sum_{i=1}^{p} \psi_{23}^{i} \Delta L E X P_{t-i}+\lambda_{2} E C T_{t-1}+u_{2 t} \\
\Delta L E X P_{t}= & c_{3}+\sum_{i=1}^{p} \psi_{31}^{i} \Delta L G D P N O N_{t-i}+\sum_{i=1}^{p} \psi_{32}^{i} \Delta L R E V O I L_{t-i} \\
& +\sum_{i=1}^{p} \psi_{33}^{i} \Delta L E X P_{t-i}+\lambda_{3} E C T_{t-1}+u_{3 t}
\end{aligned}
$$

where,

$$
E C T_{t}=L G D P N O N_{t}-\alpha_{0}-\alpha_{1} \operatorname{LREVOIL}_{t}-\alpha_{2} L E X P_{t}
$$

Once the VECM model above is estimated, the coefficients are used to compute the Impulse Response Functions (IRF) in order to demonstrate how macroeconomic variables respond to a one standard deviation positive shock in oil revenues.

\section{Results and Discussion}

\subsection{Unit Root Tests}

$\mathrm{ADF}$ and PPtests are used to test the null hypothesis of nonstationarity (or, the null of a unit root) in each of the three time series variables. We allowed the Akaike Information Criterion (AIC) to select the optimal lag length for unit root tests up to a maximum lag of 12 . Table 1 outlines the tests results.

The logarithmic levels of all variables have unit roots as the test statistics are statistically insignificant. However, the first differences of times series become stationary at the $5 \%$ significance level, indicating that each of the three variables has an order of integration of $1, \mathrm{I}(1)$. 
Table 1. Unit root tests.

\begin{tabular}{cccccc}
\hline & \multicolumn{2}{c}{ Augmented DF } & \multicolumn{2}{c}{ Phillips-Perron } & Order of \\
\cline { 2 - 5 } & Level & 1st Difference & Level & 1st Difference & Integration \\
\hline LGDPNON & -0.670 & $-6.299^{* * *}$ & -0.646 & $-6.299^{* * *}$ & I (1) \\
LREVOIL & -1.537 & $-10.224^{* * *}$ & -1.400 & $-10.683^{* * *}$ & I (1) \\
LEXP & 0.168 & $-12.688^{* * *}$ & 0.325 & $-15.333^{* * *}$ & I (1) \\
\hline
\end{tabular}

${ }^{* * *}$ Denotes rejection of the null hypothesis of a unit root at $1 \%$ level of significance.

\subsection{Cointegration and Error Correction}

The Johansen [35] cointegration test provides two types of statistics in order to determine the number of cointegrating vectors in the system of three VAR equations: Trace and Maximum Eigenvalue test statistics. Table 2 shows that both test statistics suggest the existence of one cointegrating relationship at the 5\% significance level. Therefore, there is at least one long-run equilibrium relationship among the logarithmic GDP added by the non-oil sector, government spending, and oil revenues. Furthermore, the existence of a cointegrating relationship guarantees Granger causality among these variables in at least one direction [32].

Normalizing the cointegrating vector based on LGDPNON yields the following long-run relationship:

$$
\text { LGDPNON }_{t}=0.212-0.475 \text { LREVOIL }_{t}+1.645 \text { LEXP }_{t}
$$

The long-run negative association between oil revenues and the private sector's output can be attributed to the government's fiscal behavior during high oil prices and the Arab revolutions that began in December 2010. For example, during the Arab Spring of 2011, the Omani government increased wages, salaries, social benefits, and scholarships for undergraduate studies. Furthermore, during the same period, the government employed an unnecessarily large number of job seekers in various government sectors (i.e., disguised unemployment) in response to public protests. These fiscal changes have hurt the private non-oil sectors, as many of their employees shifted to work in government jobs due to large wage gaps. Consequently, private non-oil sectors have incurred costs due to sudden loss of trained employees and having to seek and train new workers, and the performance and growth of private non-oil sectors have decreased. Conversely, the long-run positive association between government expenditures and growth in the private non-oil sectors supports the notion of that government investments are the main drivers of private sector viability in Oman, and such dependency may easily lead to vulnerability of the non-oil sector's economic growth in the case of adverse oil shocks.

In the shortrun, there may be deviations from the long-run cointegrating relationship among the three variables. The deviation from steady-state in the shortrun is represented by the addition of ECT in the short-run VECM model. The ECT represents how many periods (i.e., quarters, in our case) it takes to 
Table 2. Johansen cointegration tests.

\begin{tabular}{ccc}
\hline $\begin{array}{c}\text { Hypothesized number of } \\
\text { cointegrating vectors under the null }\end{array}$ & Trace Statistics & $\begin{array}{c}\text { Maximum Eigenvalue } \\
\text { Statistics }\end{array}$ \\
\hline None $^{*}$ & $52.822^{* *}$ & $37.372^{* *}$ \\
1 & 15.451 & 13.051 \\
\hline
\end{tabular}

Trace test and Maximum Eigenvalue statistics both indicate one cointegrating vector at $5 \%$ level. ${ }^{*}$, ${ }^{* *}$, and ${ }^{* * *}$ denote significance at $10 \%, 5 \%$, and $1 \%$ levels, respectively.

return from the short-run disequilibrium back to the long-run relationships. To ensure a mean-reverting behavior, ECT should be negative, less than one in absolute value, and significant. A significant and meaningful ECT is confirmation of a long-run causal relationship (i.e., cointegration) among LGDPNON, LREVOIL and LGDPNON. The VECM is estimated at first-differences; as such, it is inherently a short-run model and can additionally provide us shortrun causality between the three variables. Since the optimal lag length of VECM is the optimal lag of VAR minus one lag, we include nine lags in the VECM estimation. Table 3 provides the results for the VECM equation where $\triangle L G D P N O N$ is the dependent variable. The results, as displayed in Table 3, reveal that, on average, the non-oil sector's output growth responds positively to growth in oil revenues and negatively to growth in government spending in the short run. The ECM term shows that it takes about five quarters to adjust from short-run disequilibrium back to the steady state.

Three diagnostics tests are carried out for the estimated error correction equation: Breusch-Godfrey serial correlation Lagrange-Multiplier (LM) Test, White's Heteroscedasticity Test, and Jacque-Bera normality test. Results (Table 3, lower panel) suggest that the error term of the ECM does not suffer from serial correlation, heteroscedasticity, or nonnormality.

The next step of the analysis is to carry out formal tests to identify the directions of both short-run and long-run Granger causality among LGDPNON, $L R E V O I L$, and $L E X P$. Table 4 provides causality tests allowing for all possible directions. The results show that the direction of causality is from oil revenues and government spending toward the non-oil sector's GDP. In other words, LREVOIL and LEXP are Granger causes of LGDPNON in the shortrun, longrun, and jointly in the short and longrun. Again, the result is consistent with our main argument that Oman's private non-oil sector heavily depends on government spending. It exposes the weight of oil revenues as a principal driver behind the development of the Omani economy; volatility in oil revenues would quickly transfer into Oman's real sector through fiscal policies, as concluded by Ahmad and Masan [31]. In addition, Table 4 illustrates that total government spending does not respond to oil revenues in the shortrun. This result is expected as the Omani government avoids cutting government spending during negative oil price fluctuations. Moreover, revenues from oil and gas are not only allocated to the government spending category of the budget, some are allocated to reserve funds. In summary, empirical results show that both oil revenues and government 
Table 3. Estimated VECM equation based on one cointegrating vector. Dependent variable: $\triangle L G D P N O N$.

\begin{tabular}{|c|c|c|}
\hline \multicolumn{3}{|c|}{ Estimation Results: } \\
\hline Regressor & Coefficient & $\mathrm{t}$-values \\
\hline$\triangle L R E V O I L(1)$ & 0.096 & $2.805^{* * *}$ \\
\hline$\triangle L R E V O I L(2)$ & 0.072 & $1.978^{*}$ \\
\hline$\triangle L R E V O I L(3)$ & -0.007 & -0.188 \\
\hline$\triangle L R E V O I L(4)$ & -0.024 & -0.637 \\
\hline$\triangle L R E V O I L(5)$ & 0.126 & $3.166^{* * *}$ \\
\hline$\triangle L R E V O I L(6)$ & 0.197 & $4.941^{* * *}$ \\
\hline$\triangle L R E V O I L(7)$ & 0.061 & 1.314 \\
\hline$\triangle L R E V O I L(8)$ & -0.010 & -0.246 \\
\hline$\triangle L R E V O I L(9)$ & -0.015 & -0.434 \\
\hline$\triangle L E X P(1)$ & -0.202 & $-1.923^{*}$ \\
\hline$\triangle L E X P(2)$ & -0.267 & $-2.830^{* * *}$ \\
\hline$\triangle L E X P(3)$ & -0.343 & $-3.935^{\star * *}$ \\
\hline$\triangle L E X P(4)$ & -0.363 & $-3.940^{* * *}$ \\
\hline$\triangle L E X P(5)$ & -0.236 & $-2.514^{\star *}$ \\
\hline$\triangle L E X P(6)$ & -0.095 & -1.229 \\
\hline$\triangle L E X P(7)$ & -0.041 & -0.628 \\
\hline$\triangle L E X P(8)$ & -0.050 & -0.855 \\
\hline$\triangle L E X P(9)$ & -0.099 & $-2.368^{\star *}$ \\
\hline$E C T$ & -0.171 & $-1.894^{*}$ \\
\hline$C$ & 0.006 & 1.433 \\
\hline \multicolumn{3}{|c|}{ Diagnostic Tests: } \\
\hline Test & Statistics & $\mathrm{p}$-value \\
\hline LM Test (Serial Correlation) & 1.067 & 0.435 \\
\hline White Test (Heteroskedasticity) & 0.488 & 0.967 \\
\hline Jarque-Bera Normality Test & 1.825 & 0.401 \\
\hline
\end{tabular}

${ }^{*}, * *$, and ${ }^{* *}$ denote significance at $10 \%, 5 \%$, and $1 \%$ levels, respectively.

Table 4. Causality tests based on the VECM.

\begin{tabular}{|c|c|c|c|c|c|c|c|}
\hline \multirow{2}{*}{ Variables } & \multicolumn{3}{|c|}{ Short run causality (F-stats) } & \multirow{2}{*}{$\begin{array}{l}\text { Long-run causality } \\
\quad \text { (ECTt-stats) }\end{array}$} & \multicolumn{3}{|c|}{ Joint short- \& long-run causality (F-stats) } \\
\hline & $\triangle L G D P N O N$ & $\triangle L R E V O I L$ & $\triangle L E X P$ & & $\triangle L G D P N O N \& E C T$ & $\triangle L R E V O I L \& E C T$ & $\triangle L E X P \& E C T$ \\
\hline$\triangle L G D P N O N$ & - & $4.493^{* * *}$ & $3.555^{\star * *}$ & $-0.171^{*}$ & - & $4.059^{* * *}$ & $3.233^{\star * *}$ \\
\hline$\triangle L R E V O I L$ & 0.431 & - & 0.783 & 0.202 & 0.390 & - & 0.706 \\
\hline$\triangle L E X P$ & 0.481 & 1.063 & - & $0.885^{\star}$ & 0.882 & 1.207 & - \\
\hline
\end{tabular}


expenditures are causal factors influencing the output level and GDP growth of the private non-oil sectors in Oman.

\subsection{Generalized Impulse Response Functions (GIRFs)}

The impulse response functions (IRFs) depict the reaction of a variable of interest in a dynamic system to an external shock to another variable in the same system [37]. Moreover, IRFs illustrate the number of periods it takes for the response variable to go back to long-run equilibrium after a one standard deviation shock in the impulse variable.

Figure 2 presents the generalized impulse response functions (GIRFs) for each variable. For example, the response of $L G D P N O N$ to a one standard deviation shock in LREVOIL is negative for about the first five quarters (or, about 15 months) and is positive afterward. Similarly, the response of $L G D P N O N$ to a one standard deviation shock in $L E X P$ is initially negative, but it becomes positive after about five quarters. For the reaction of the government expenditures, the graphs display that the response of LEXP to a shock caused by LREVOIL is
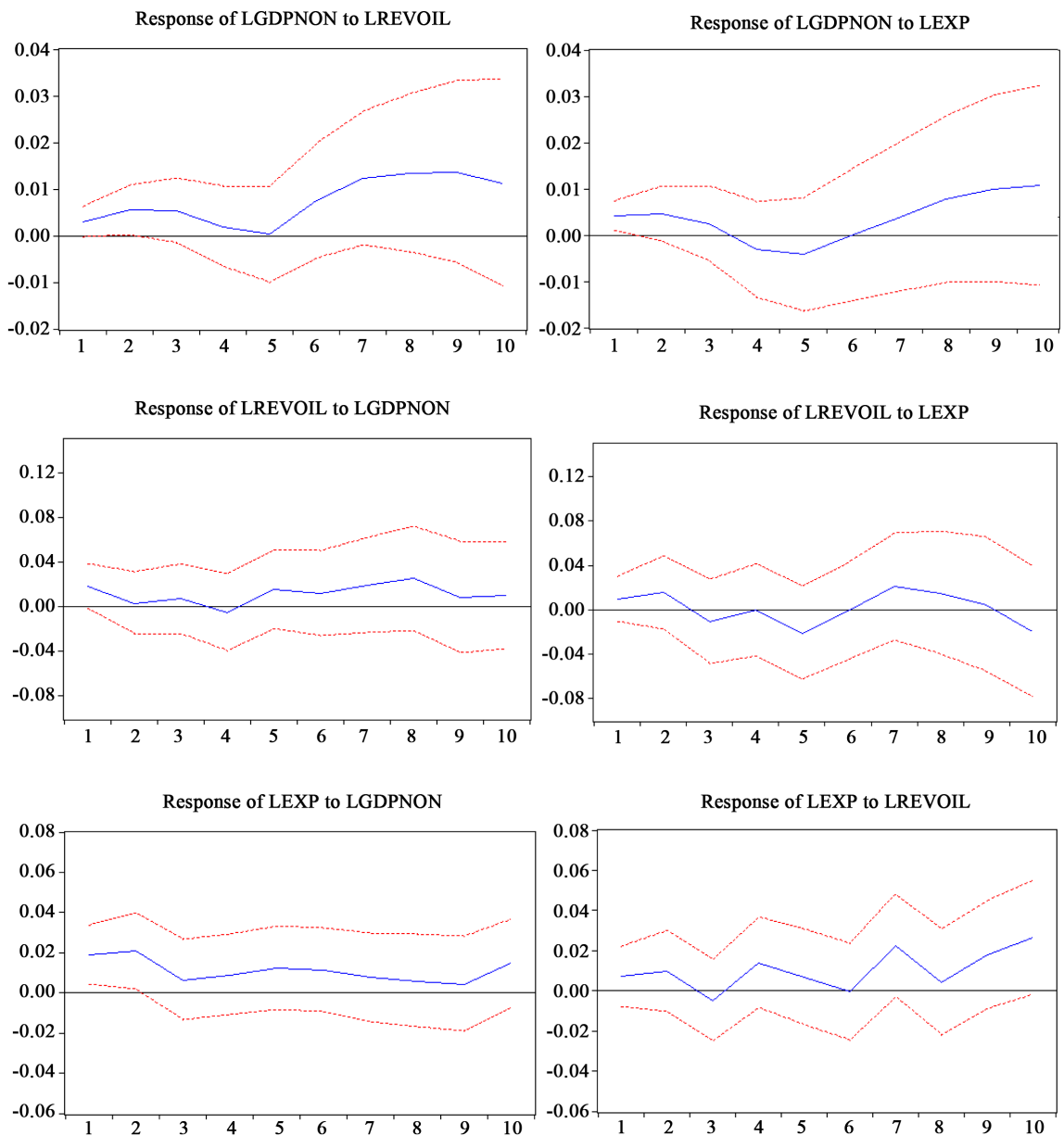

Figure 2. Generalized impulse response functions. (Note: The horizontal axis represents time elapsed in quarters. Vertical axis represents magnitude of the response in percentage after a one-standard deviation impulse). 
highly persistent for a while and then becomes insignificant after the tenth quarter. This persistent behavior of LEXP is a common finding [38] [39] [40] [41]. The GIRFs indicate that the responses are substantial and the process of adjustment to the long-run equilibrium is not fast, likely due to the most recent oil revenue volatility that has slowed down the economic growth in most oil-exporting countries.

\section{Conclusions}

Oil is considered the main driver of economic activity in Oman, as the country is heavily dependent on oil revenues. This dependency is reflected in the shares of oil revenues in total government revenues, total exports, and gross domestic product (GDP). Oman's government uses its revenues from oil to modernize infrastructure, create additional employment, and improve social indicators when the oil markets are in a boom cycle. However, due to falling oil prices in recent years, oil revenues have decreased. Non-oil sectors could be considered an alternative, attractive source of income for an oil-dependent country to restore economic growth in case of oil revenue shock. However, if the development of the non-oil sectors is tied to public projects fueled by oil revenues, the performance of non-oil sectors during oil price shocks will only aggravate the decline in economic growth. The recent crash in oil prices has exposed such vulnerability in Oman's economy. Because the use of monetary policy in Oman is limited by its fixed exchange rate policy, fiscal policy is used to navigate the economy through an oil revenue shock. However, this is problematic as government spending itself is tied to the stream of oil revenues, and the private non-oil sector is dependent on government spending; therefore, fiscal policy may be exacerbating the adverse effects of oil shocks on the economic growth of the non-oil sector.

The complex role of government spending on the non-oil sector in Oman motivated us to investigate the short-run and long-run causal linkages among oil revenues, government expenditures, and output and growth in the private nonoil sectors. Using Vector Autoregressive (VAR) models and cointegration techniques, coupled with quarterly data covering the period 2000 to 2015, we explore both the "oil-curse" phenomenon for Oman and whether public spending in the private sector worsens the outcome. We find a long-run cointegrating relationship between oil revenues, government expenditures, and GDP added by the private non-oil sector in Oman. In the longrun, oil revenues decrease the non-oil sector's contribution to the overall GDP, while government spending increases non-oil GDP. However, in the short run, on average, GDP growth in the non-oil sector responds positively to the growth in oil revenues and negatively to the growth in government spending. This short-run disequilibrium takes about fifteen months to correct itself back to the aforementioned steady-state relationship. The causality tests verify that the direction of both short-run and long-run causality is from government spending and oil revenues toward the economic growth and GDP in the non-oil sector. 
Our findings are consistent with policies recommended by the International Monetary Fund (IMF) to mitigate current and future oil shocks in Oman. While some oil exporting Arab countries have a long oil production horizon, hydrocarbon resources in Oman are expected to be depleted in the foreseeable future [42]. The government's capacity to support the economic growth of the non-oil sector may be impaired if no action is taken to develop an oil-independent fiscal policy and a diverse non-oil sector that is self-sufficient and not reliant on public investment in the longrun. Sustaining long-run growth requires developing nonoil sectors that can provide alternative sources of revenues as the oil and gas industry shrinks. Strong private investment can become the engine for economic growth when large public investment in the non-oil sector can no longer be maintained. This would raise non-oil production and compensate the future losses of government revenues from diminishing oil reserves or persistent oil price shocks. A diverse, export-oriented non-oil sector would also help with the sustainability of the current account balance and provide a steadier way of reserve accumulation. The development of a vibrant non-oil sector would also provide new employment opportunities for the citizens of Oman. This should place a greater burden on the fiscal authorities to ensure that oil revenues are being allocated to their best uses that maximize long-run growth rates.

\section{Acknowledgements}

The authors would like to thank Mr. Al-Mudhaffar and the team at National Centre for Statistics \& Information, Oman for providing the data.

\section{Conflicts of Interest}

The authors declare no conflicts of interest regarding the publication of this paper.

\section{References}

[1] Nusair, S.A. (2016) The Effects of Oil Price Shocks on The Economies of The Gulf Co-Operation Council Countries: Nonlinear Analysis. Energy Policy, 91, 256-267. https://doi.org/10.1016/j.enpol.2016.01.013

[2] Esfahani, H.S., Mohaddes, K. and Pesaran, M.H. (2014) An Empirical Growth Model for Major Oil Exporters. Journal of Applied Econometrics, 29, 1-21. https://doi.org/10.1002/jae.2294

[3] Omani Economic Association (2013) Conference on Sustainable Development and Equity: Between Planning and Reality. Omani Economic Association, Muscat, Oman, 16-17 February 2013.

[4] El Anshasy, A.A. and Bradley, M.D. (2012) Oil Prices and the Fiscal Policy Response in Oil-Exporting Countries. Journal of Policy Modeling, 34, 605-620. https://doi.org/10.1016/j.jpolmod.2011.08.021

[5] Hamdi, H. and Sbia, R. (2013) Dynamic Relationships between Oil Revenues, Government Spending and Economic Growth in an Oil-Dependent Economy. Economic Modelling, 35, 118-125. https://doi.org/10.1016/j.econmod.2013.06.043

[6] Cashin, P., Liang, H. and McDermott, C. (2000) How Persistent Are Shocks to 
World Commodity Prices? IMF Staff Papers, 47, 177-217.

https://www.imf.org/external/Pubs/FT/staffp/2000/00-02/pdf/cashin.pdf

[7] Hausmann, R., Powell, A. and Rigobon, R. (1993) An Optimal Spending Rule Facing Oil Income Uncertainty (Venezuela). In: Engel, E. and Meller, P., Eds., External Shocks and Stabilization Mechanisms, Inter-American Development Bank, Washington DC.

[8] Talvi, E. and Vegh, C.A. (2000) Tax Base Variability and Procyclical Fiscal Policy. National Bureau of Economic Research. Journal of Development Economics, 78, 156-190. https://www.nber.org/papers/w7499 https://doi.org/10.3386/w7499

[9] Lilien, D.M. (1982) Sectoral Shifts and Cyclical Unemployment. Journal of Political Economy, 90, 777-793. https://doi.org/10.1086/261088

[10] Davis, J., Ossowski, R., Daniel, J., Barnett, S., et al. (2001) Stabilization and Savings Funds for Nonrenewable Resources: Experience and Fiscal Policy Implications. International Monetary Fund (IMF), Occasional Paper No. 205.

[11] Frankel, J.A. (1999) No Single Currency Regime Is Right for All Countries or at All Times. National Bureau of Economic Research, Cambridge, MA, NBER Working Paper No. 7338

[12] Farzanegan, M.R. and Markwardt, G. (2009) The Effects of Oil Price Shocks on the Iranian Economy. Energy Economics, 31, 134-151. https://doi.org/10.1016/j.eneco.2008.09.003

[13] Alkhathlan, K. (2013) Contribution of Oil in Economic Growth of Saudi Arabia. Applied Economic Letters, 20, 343-348. https://doi.org/10.1080/13504851.2012.703310

[14] Corden, W.M. and Peter, N.J. (1982) Booming Sector and De-Industrialisation in a Small Open Economy. The Economic Journal, 92, 825-848. https://doi.org/10.2307/2232670

[15] Krugman, P. (1987) The Narrow Moving Band, The Dutch Disease, and the Competitive Consequences of Mrs. Thatcher: Notes on Trade in the Presence of Dynamic Scale Economies. Journal of Development Economics, 27, 41-55. https://doi.org/10.1016/0304-3878(87)90005-8

[16] Corden, W.M. (1984) Booming Sector and Dutch Disease Economics: Survey and Consolidation. Oxford Economic Papers, 36, 359-380. https://doi.org/10.1093/oxfordjournals.oep.a041643

[17] Sachs, J.D. and Warner, A.M. (1995) Natural Resource Abundance and Economic Growth. National Bureau of Economic Research, Cambridge, MA, NBER Working Paper No. w5398. https://www.nber.org/papers/w5398 https://doi.org/10.3386/w5398

[18] Elwerfelli, A. and Benhin, J. (2018) Oil a Blessing or Curse: A Comparative Assessment of Nigeria, Norway and the United Arab Emirates. Theoretical Economics Letters, 8, 1136-1160. https://doi.org/10.4236/tel.2018.85076

[19] Brunnschweiler, C.N. and Bulte, E.H. (2008) The Resource Curse Revisited and Revised: A Tale Of Paradoxes And Red Herrings. Journal of Environmental Economics and Management, 55, 248-264. https://doi.org/10.1016/j.jeem.2007.08.004

[20] Caselli, F. and Cunningham, T. (2009) Leader Behaviour and the Natural Resource Curse. Oxford Economic Papers, 61, 628-650. https://doi.org/10.1093/oep/gpp023

[21] Cavalcanti T.V.V., Mohaddes, K. and Raissi, M. (2011) Growth, Development and Natural Resources: New Evidence Using a Heterogeneous Panel Analysis. The Quarterly Review of Economics and Finance, 51, 305-318. 
https://doi.org/10.1016/j.qref.2011.07.007

[22] Eltony, M.N. and Al-Awadi, M. (2001) Oil Price Fluctuations and Their Impact on the Macroeconomic Variables of Kuwait: A Case Study Using a VAR Model. International Journal of Energy Research, 25, 939-959. https://doi.org/10.1002/er.731

[23] Ayadi, O.F. (2005) Oil Price Fluctuations and the Nigerian Economy. OPEC Review, 29, 199-217. https://doi.org/10.1111/j.0277-0180.2005.00151.x

[24] Iwayemi, A. and Fowowe, B. (2011) Impact of Oil Price Shocks on Selected Macroeconomic Variables in Nigeria. Energy Policy, 39, 603-612.

https://doi.org/10.1016/j.enpol.2010.10.033

[25] Mehrara, M. (2008) The Asymmetric Relationship between Oil Revenues and Economic Activities: The Case of Oil-Exporting Countries. Energy Policy, 36, 1164-1168. https://doi.org/10.1016/j.enpol.2007.11.004

[26] Akpan, E.O. (2009) Oil Price Shocks and Nigeria's Macroeconomy. Proceedings of the CSAE Conference, Economic Development in Africa, Oxford, UK, 17-19 March 2019.

[27] Jbir, R. and Zouari-Ghorbel, S. (2009) Recent Oil Price Shock and Tunisian Economy. Energy Policy, 37, 1041-1051. https://doi.org/10.1016/j.enpol.2008.10.044

[28] Cologni, A. and Manera, M. (2013) Exogenous Oil Shocks, Fiscal Policies and Sector Reallocations in Oil Producing Countries. Energy Economics, 35, 42-57. https://doi.org/10.1016/j.eneco.2011.11.020

[29] Moshiri, S. and Banijasham, A. (2012) Asymmetric Effects of Oil Price Shocks on Economic Growth of Oil-Exporting Countries. USAEE Working Paper No. 12-140. https://doi.org/10.2139/ssrn.2163306

[30] Berument, H. and Ceylan, N.B. (2010) The Impact of Oil Price Shocks on the Economic Growth of the Selected MENA Countries. The Energy Journal, 31, 149-176.

[31] Ahmad, A.H. and Masan, S. (2015) Dynamic Relationships between Oil Revenue, Government Spending, and Economic Growth in Oman. International Journal of Business and Economic Development, 3, 93-115.

[32] Engle, R.F. and Yoo, S. (1987) Forecasting and Testing in Cointegrated Systems. Journal of Econometrics, 35, 143-159. https://doi.org/10.1016/0304-4076(87)90085-6

[33] Dickey, D.A. and Fuller, W.A. (1981). Likelihood Ratio Statistics for Autoregressive Time Series with a Unit Root. Econometrica, 49, 1057-1072. https://doi.org/10.2307/1912517

[34] Phillips, P.C.B. and Perron, P. (1988) Testing for a Unit Root in Time Series Regression. Biometrika, 75, 336-346. https://doi.org/10.1093/biomet/75.2.335

[35] Johansen, S. (1988) Statistical Analysis of Cointegration Vectors. Journal of Economic Dynamics and Control, 12, 231-254.

https://doi.org/10.1016/0165-1889(88)90041-3

[36] Pao, H.T. and Tsai, C.M. (2010) $\mathrm{CO}_{2}$ Emissions, Energy Consumption and Economic Growth in BRIC Countries. Energy Policy, 38, 7850-7860. https://doi.org/10.1016/j.enpol.2010.08.045

[37] Pesaran, H.H. and Shin, Y. (1998) Generalized Impulse Response Analysis in Linear Multivariate Models. Economics Letters, 58, 17-29. https://doi.org/10.1016/S0165-1765(97)00214-0

[38] Blanchard, O. and Perotti, R. (2002) An Empirical Characterization of the Dynamic Effects of Changes in Government Spending and Taxes on Output. The Quarterly Journal of Economics, 117, 1329-1368. 
https://doi.org/10.1162/003355302320935043

[39] Perotti, R. (2004) Estimating the Effects of Fiscal Policy in OECD Countries. Bocconi University, Milano, Italy, IGIER Working Paper No. 276.

[40] Fatas, A. and Mihov, I. (2001) The Effects of Fiscal Policy on Consumption and Employment: Theory and Evidence. Centre for Economic Policy Research, London, UK, CEPR Discussion Paper No. 2760.

[41] Parkyn, O. and Vehbi, T. (2014) The Effects of Fiscal Policy in New Zealand: Evidence from a VAR Model with Debt Constraints. Economic Record, 90, 345-364. https://doi.org/10.1111/1475-4932.12116

[42] IMF (2016) Economic Diversification in Oil-Exporting Arab Countries. IMF Policy Papers, 29 April 2016.

https://www.imf.org/en/Publications/Policy-Papers/Issues/2016/12/31/Economic-D iversification-in-Oil-Exporting-Arab-Countries-PP5038 